\title{
MEMPERTAHANKAN INTEGRASI NASIONAL DENGAN KOMUNIKASI ANTAR BUDAYA
}

\author{
Suraya \\ Universitas Paramadina \\ Jl. Gatot Subroto, Jakarta \\ suraya@paramadina.ac.id
}

\begin{abstract}
Intercultural communication has a role in solving conflicts in Indonesia which has various cultures. Intercultural communication can enhance national integration through mutual understanding and tolerance among each culture and cultural diversity in society. Indonesian society where national identity as part of nation of Indonesia in the intercultural communication together can create the fabric of brotherhood in order to realize the diversity within the unity of Indonesia's National Integration.
\end{abstract}

Keywords: Intercultural Communication, Integration

\begin{abstract}
Abstrak: Komunikasi Antar Budaya memiliki peran dalam penyelesaian konflik di Indonesia yang memiliki budaya masyarakat yang beragam. Komunikasi antar budaya dapat meningkatkan integrasi nasional melalui adanya saling pengertian dan toleransi dalam berbagai keragaman budaya yang ada di masyarakat. Masyarakat Indonesia dengan identitas nasional sebagai bangsa Indonesia, dalam komunikasi antar budaya bersama-sama menciptakan jalinan persaudaraan dalam rangka mewujudkan keragaman dalam kesatuan Integrasi Nasional Indonesia
\end{abstract}

Kata Kunci: Komunikasi Antar Budaya, Integrasi

\section{Pendahuluan}

Saat ini bangsa Indonesia banyak menghadapi konflik yang intensitasnya cenderung meningkat. Konflik tersebut misalnya konflik sosial yang bernuansa separatis: konflik sosial di Nanggroe Aceh Darusalam, Maluku dan Papua; konflik sosial yang bernuansa etnis: konflik di Sambas, Sampit, Sanggauledo, Poso dan Maluku; konflik sosial bernuansa ideologis: isu paham komunis, faham radikalisme; konflik sosial bernuansa politis: konflik akibat isu kecurangan pilkada, isu pemekaran wilayah di beberapa wilayah yang berakibat penyerangan dan perusakan; konflik sosial bernuansa ekonomi: konflik antar kelompok nelayan di selat Madura, antar kelompok preman, antar kelompok pengemudi, antar kelompok pedagang; konflik sosial lainnya: konflik antar anak sekolah, mahasiswa; konflik bernuansa solidaritas liar: tawuran antar wilayah, antar gang motor, antar supporter sepak bola; konflik sosial isu agama atau aliran kepercayaan: isu berkaitan dengan aliran Achmadiyah, isu aliran sesat; konflik isu kebijakan pemerintah: bahan bakar Minyak (BBM), Bantuan Operasional Sekolah (BOS) dan Gas LPG. Belum lagi permasalahan korupsi yang sudah sedemikian parah dengan berbagai penyimpangan yang tidak saja dilakukan oleh aparat birokrasi tetapi juga oleh wakil rakyat. Pelaksanaan penegakan hukum 
masih jauh dari harapan, kualitas pelayanan kesehatan dan pendidikan masyarakat yang semakin memprihatinkan akhirnya menyebabkan kemiskinan dimana-mana. Seperti inilah gambaran Negara Indonesia.

Setiap warga Negara tentunya tidak menghendaki berbagai konflik dan persoalan sosial kemasyarakatan yang berdimensi kekerasan akan menjadi pemicu timbulnya kerusakan sosial, perpecahan bangsa dan terjadi disintegrasi bangsa ini terus berlangsung.

Masyarakat Indonesia secara demografis maupun sosiologis merupakan perwujudan masyarakat yang pluralis. Indonesia memiliki semboyan Bhineka Tunggal Ika yang mengharuskan kita untuk mengakui dan menghormati keberagaman sebagai sebuah kekayaan bangsa dan memahami perbedaan budaya, agama, politik, ideologi dan lain-lain sehingga muncul sifat toleransi, tolong menolong dan gotong royong antar umat beragama.

Namun kondisi masyarakat Indonesia yang plural/berbeda-beda cenderung mempermudah munculnya disintegrasi nasional. Sehingga masyarakat Indonesia harus benarbenar siap menghadapi situasi atau peristiwa baru dalam keragaman kebudayaan yang bisa memicu pergesekan diantara anggota masyarakat Indonesia.

Apabila kita mencermati permasalahan pluralitas dan kondisi masyarakat Indonesia yang rawan disintegrasi nasional, ternyata ada persoalan lain yang bisa menjadi hambatan dalam penyelesaian disintegrasi nasional, seperti: (1) Masih banyak masyarakat Indonesia yang tingkat pendidikannya rendah, akses terhadap fasilitas komunikasi masih kurang terjangkau sehingga penyerapan dan pengembangan nilai-nilai baru yang positif terbatas dan mudah terprovokasi isuisu negatif. (2) Peran media komunikasi kurang maksimal. (3) meningkatnya gejala "social crisis on caring" (krisis pengasuhan dan kepedulian di dalam masyarakat) sehingga masyarakat menjadi tidak peduli terhadap lingkungan sekitarnya.

Perbedaan atau pluralitas budaya ini justru seringkali menjadi pemicu munculnya konflik suku bangsa, agama, ras dan antar golongan (SARA), walaupun sebenarnya faktor-faktor penyebab dari konflik tersebut adalah persoalan-persoalan politik, kemiskinan, ketidakadilan sosial dan kesenjangan ekonomi. Komunikasi dalam konteks keragaman budaya seringkali mengalami hambatan dan kendala. Misalnya: penggunaan bahasa, lambang-lambang, nilai atau norma-norma masyarakat dan lain sebagainya. Padahal syarat untuk terjalinnya hubungan itu tentu saja harus ada saling pengertian dan pertukaran informasi atau makna antara satu dengan lainnya. Komunikasi dan budaya mempunyai hubungan timbal balik, seperti dua sisi mata uang. Budaya menjadi bagian dari perilaku komunikasi dan pada gilirannya komunikasi pun turut menentukan memelihara, mengembangkan atau mewariskan budaya seperti yang dikatakan 
Edward T. Hall bahwa komunikasi adalah budaya dan budaya adalah komunikasi, yang kesemuanya dapat diarahkan untuk mewujudkan terciptanya integrasi nasional. Tulisan ini akan membahasnya dari sisi komunikasi antar budaya maka kita bisa melihatnya dari sisi konflik sosial yang bernuansa etnis: konflik di Sambas, Sampit, Sanggauledo, Poso dan Maluku. Konflik etnis yang terjadi di beberapa daerah ini dapat mengakibatkan disintegrasi bangsa atau perpecahan di Negara kita. Lalu yang jadi pertanyaan adalah: Apakah pendekatan komunikasi antar budaya dapat menyelesaikan konflik antar etnis? Apakah pendekatan komunikasi antar budaya dapat mencegah terjadinya dis-integrasi nasional?

\section{Pembahasan}

Sebelumnya penulis menguraikan mengenai konflik. Menurut Fisher (2000) konflik dapat dijelaskan dari beberapa teori, yaitu: (1) Teori Hubungan Masyarakat yang menganggap bahwa konflik disebabkan oleh polarisasi yang terus terjadi, ketidakpercayaan dan permusuhan diantara kelompok yang berbeda dalam suatu masyarakat. Sasaran yang ingin dicapai teori ini adalah: a) Meningkatkan komunikasi dan saling pengertian antara kelompok-kelompok yang mengalami konflik, b) Mengusahakan toleransi dan agar masyarakat lebih bisa saling menerima keragaman yang ada di dalamnya. (2) Teori Negosiasi Prinsip menganggap bahwa konflik disebabkan oleh posisi-posisi yang tidak selaras dan perbedaan pandangan tentang konflik oleh pihak-pihak yang mengalami konflik. Sasaran yang ingin dicapai teori ini adalah: a) Membantu pihak-pihak yang mengalami konflik untuk memisahkan perasaan pribadi dengan berbagai masalah dan isu, dan memampukan mereka untuk melakukan kepentingan-kepentingan mereka daripada posisi tertentu yang sudah tetap. b) Melancarkan proses pencapaian kesepakatan yang menguntungkan kedua belah pihak atau semua pihak. (3) Teori Kebutuhan Manusia berasumsi bahwa konflik yang berakar dalam disebabkan oleh kebutuhan dasar manusia - fisik, mental, dan sosial - yang tidak terpenuhi atau dihalangi. Keamanan, identitas, pengakuan, partisipasi, dan otonomi sering merupakan inti pembicaraan. Sasaran yang ingin dicapai teori ini adalah: a) Membantu pihak-pihak yang mengalami konflik untuk mengidentifikasi dan mengupayakan bersama keutuhan mereka yang tidak terpenuhi, dan menghasilkan pilihan-pilihan untuk memenuhi kebutuhan-kebutuhan itu. b) Agar pihak-pihak yang mengalami konflik mencapai kesepakatan untuk memenuhi kebutuhan dasar semua pihak. (3) Teori Identitas berasumsi bahwa konflik disebabkan karena identitas yang terancam, yang sering berakar pada hilangnya sesuatu atau penderitaan di masa lalu yang tidak diselesaikan. Sasaran yang ingin dicapai teori ini adalah: a) Melalui fasilitasi lokakarya dan dialog antara pihak-pihak yang mengalami konflik 
mereka diharapkan dapat mengidentifikasi ancaman-ancaman dan ketakutan yang mereka rasakan masing-masing dan untuk membangun empati dan rekonsiliasi antara mereka. b) Meraih kesempatan bersama yang mengakui kebutuhan identitas pokok semua pihak. (4) Teori Kesalahpahaman Budaya berasumsi bahwa konflik yang disebabkan oleh ketidakcocokan dalam cara-cara komunikasi diantara berbagai budaya yang berbeda. Sasaran yang ingin dicapai teori ini adalah: a) Menambah pengetahuan pihak-pihak yang mengalami konflik mengenai budaya pihak lain, b) Mengurangi stereotip negatif yang mereka miliki tentang pihak lain, c) Meningkatkan keefektifan komunikasi antar budaya. (5) Teori Transformasi Konflik berasumsi bahwa konflik disebabkan oleh masalah-masalah ketidaksetaraan dan ketidakadilan yang muncul sebagai masalah-masalah sosial, budaya dan ekonomi. Sasaran yang ingin dicapai teori ini adalah: a) Mengubah berbagai struktur dan kerangka kerja yang menyebabkan ketidaksetaraan dan ketidakadilan, termasuk kesenjangan ekonomi, b) Meningkatkan jalinan hubungan dan sikap jangka panjang diantara pihak-pihak yang mengalami konflik, c) Mengembangkan berbagai proses dan sistem untuk mempromosikan pemberdayaan, keadilan, perdamaian, pengampunan, rekonsiliasi, pengakuan. Tulisan ini akan membahas konflik dengan pendekatan komunikasi antar budaya.

Hubungan antara budaya dan komunikasi penting untuk memahami komunikasi antar budaya, oleh karena itu, melalui pengaruh budayalah orang-orang belajar berkomunikasi. Perilaku mereka dapat mengandung makna, sebab perilaku tersebut dipelajari dan diketahui; dan perilaku itu terikat oleh budaya. Orang-orang memandang dunia mereka melalui kategorikategori, konsep-konsep dan label-label yang dihasilkan budaya mereka.

Kemiripan budaya dalam persepsi memungkinkan pemberian makna yang mirip pula terhadap suatu objek sosial atau suatu peristiwa. Cara-cara kita berkomunikasi, keadaan-keadaan komunikasi kita, bahasa dan gaya bahasa yang kita gunakan, dan perilaku-perilaku nonverbal kita, semua itu merupakan respon terhadap dan fungsi budaya kita. Komunikasi itu terikat budaya. Sebagaimana budaya berbeda antara satu dengan yang lainnya, maka praktek dan perilaku komunikasi individu-individu yang diasuh dalam budaya-budaya tersebut pun akan berbeda pula.

Budaya adalah suatu pola hidup menyeluruh. Budaya bersifat kompleks, abstrak, dan luas. Banyak aspek budaya turut menentukan perilaku komunikatif. Unsur-unsur sosio budaya ini tersebar dan meliputi banyak kegiatan sosial manusia. Unsur-unsur sosio budaya ini merupakan bagian dari komunikasi antar budaya. Bila kita memadukan unsur-unsur tersebut sebagaimana yang kita lakukan ketika kita berkomunikasi, unsur-unsur tersebut bagaikan 
komponen-komponen suatu sistem stereo setiap komponen berhubungan dengan dan membutuhkan komponen lainnya. Unsur-unsur tersebut tidak terisolasi dan tidak berfungsi sendiri-sendiri, mereka membentuk suatu matriks yang kompleks mengenai unsur-unsur yang sedang berinteraksi yang beroperasi bersama-sama, yang merupakan fenomena kompleks yang disebut komunikasi antar budaya (Mulyana, 1996).

Perilaku-perilaku ini dipelajari sebagai bagian dari pengalaman budaya mereka. Baik dalam menilai kecantikan atau melukiskan salju, kita memberikan respons kepada stimuli tersebut sedemikian rupa sebagaimana yang budaya kita telah ajarkan kepada kita. Kita cenderung memperhatikan, memikirkan dan memberikan respons kepada unsur-unsur dalam lingkungan kita yang penting bagi kita. Di Amerika Serikat, orang mungkin merespons terutama ukuran dan harga sesuatu, sedangkan bagi orang Jepang, warna mungkin merupakan kriteria lain yang penting. Budaya cenderung menentukan kriteria mana yang penting ketika kita mempersepsi sesuatu.

Komunikasi antar budaya akan lebih dapat dipahami sebagai perbedaan budaya dalam mempersepsi objek-objek sosial dan kejadian-kejadian. Suatu prinsip penting dalam pendapat ini adalah bahwa masalah-masalah kecil dalam komunikasi sering diperumit oleh perbedaanperbedaan persepsi ini. Untuk memahami dunia dan tindakan-tindakan orang lain, kita harus memahami kerangka persepsinya. Kita harus belajar memahami bagaiman mempersepsi dunia. Dalam komunikasi antar budaya yang ideal kita akan mengharapkan banyak persamaan dalam pengalaman dan persepsi. Tetapi karakter budaya cenderung memperkenalkan kita kepada pengalaman-pengalaman yang tidak sama, dan oleh karenanya, membawa kita kepada persepsi yang berbeda-beda atas dunia eksternal.

Tiga unsur sosio-budaya mempunyai pengaruh yang besar dan langsung atas maknamakna yang kita bangun dalam persepsi kita. Unsur-unsur tersebut adalah sistem-sistem kepercayaan(belief), nilai (value), sikap (attitude); pandangan dunia (worlds view) dan organisasi sosial (social organization). Ketika ketiga unsur utama ini mempengaruhi persepsi kita dan makna yang kita bangun dalam persepsi, unsur-unsur tersebut mempengaruhi aspek-aspek makna yang bersifat pribadi dan subjektif. Kita semua mungkin melihat entitas sosial yang sama dan menyetujui entitas sosial tersebut dengan menggunakan istlah-istilah yang objektif, tetapi makna objek atau peristiwa tersebut bagi kita sebagai individu mungkin sangat berbeda. Seorang Arab dan seorang Amerika akan setuju secara objektif bahwa seseorang tertentu adalah wanita. Tetapi kemungkinan besar mereka tidak akan setuju tentang apa arti seorang wanita secara 
sosial. Masing-masing dari ketiga unsur utama sosio-budaya tersebut akan dibahas untuk menunjukkan bagaimana unsur-unsur tersebut mempengaruhi persepsi (Mulyana, 1996).

Larry A. Samovar dan Richard E. Porter mengemukakan enam unsur budaya yang secara langsung mempengaruhi persepsi kita ketika berkomunikasi dengan orang dari budaya lain, yakni: Kepercayaan (beliefs), nilai (Values) dan sikap (attitudes); Pandangan dunia (worldview); Organisasi Sosial (Social Organization); Tabiat manusia (Human Nature); Orientasi Kegiatan (Activity Orientation); Persepsi tentang diri dan orang lain (perception of self and others).

Kita dapat mengalami peristiwa yang sama dan sepakat mengenai apa yang kita lihat secara fisik. Namun kita sering berbeda dalam memaknai peristiwa atau objek yang kita lihat. Berbagai orang dari berbagai budaya dapat setuju bahwa seseorang tertentu adalah perempuan, namun kemungkinan besar tidak sepakat apakah perempuan itu secara sosial dan juga bagaimana bereaksi terhadap makhluk tersebut.

Komunikasi antar budaya (intercultural communication) adalah proses pertukaran pikiran dan makna antara orang-orang berbeda budaya. Ketika komunikasi terjadi antara orang-orang berbeda bangsa, kelompok, ras atau komunitas bahasa, komunikasi tersebut disebut komunikasi antar budaya. Menurut Mulyana (1996) komunikasi antar budaya adalah komunikasi yang terjadi antara orang-orang yang berbeda bangsa, ras, bahasa, agama, tingkat pendidikan, status sosial atau bahkan jenis kelamin.

Sementara Gudykunst dan Kim berpendapat pengaruh budaya meliputi faktor-faktor yang menjelaskan kemiripan dan perbedaan budaya, misalnya pandangan dunia (agama), bahasa, juga sikap kita terhadap manusia, misalnya apakah kita harus peduli terhadap individu (individualisme) atau terhadap kolektivitas (kolektivisme). Faktor-faktor tersebut mempengaruhi nilai, norma dan aturan yang mempengaruhi perilaku komunikasi kita. Pengaruh sosiobudaya adalah pengaruh yang menyangkut proses penataan sosial (social ordering process). Penataan sosial berkembang berdasarkan interaksi dengan orang lain ketika pola-pola perilaku menjadi konsisten dengan berjalannya waktu. Sosiobudaya ini terdiri dari empat faktor utama: (1). Keanggotaan kita dalam kelompok sosial, konsep diri kita, ekspektasi peran kita dan definisi kita mengenai hubungan antar pribadi. Dimensi psikobudaya mencakup proses penataan pribadi (personal ordering process). Penataan pribadi ini adalah proses yang memberi stabilitas pada proses psikologis. Faktor-faktor psikobudaya ini meliputi stereotip dan sikap (misalnya etnosentrisme dan prasangka) terhadap kelompok lain. Stereotip dan sikap kita menciptakan pengharapan mengenai bagaimana orang lain akan berperilaku. Pengharapan kita itu pada gilirannya mempengaruhi cara kita menafsirkan rangsangan yang datang dan prediksi yang kita 
buat mengenai perilaku orang lain. Etnosentrisme, misalnya, mendorong kita menafsirkan perilaku orang lain berdasarkan kerangka rujukan kita sendiri dan mengharapkan orang lain berperilaku sama seperti kita. Hal ini akan membuat kita salah menafsirkan pesan orang lain dan meramalkan perilakunya yang akan datang secara salah pula.

Komunikasi antar budaya pertama kali diperkenalkan oleh antropolog Edward Hall (Mulyana, 1996) lebih dari empat dekade lalu. Komunikasi antar budaya pada dasarnya mengkaji :

Bagaimana budaya berpengaruh terhadap aktivitas komunikasi,

Apa makna pesan verbal dan nonverbal menurut budaya-budaya yang bersangkutan,

Apa yang layak dikomunikasikan,

Bagaimana cara mengkomunikasikannya (verbal dan nonverbal)

Kapan mengkomunikasikannya, dan sebagainya.

Komunikasi lintas budaya (cross cultural communication) secara tradisional membandingkan fenomena komunikasi dalam budaya-budaya berbeda. Misalnya bagaimana gaya komunikasi pria atau gaya komunikasi wanita dalam budaya Amerika dan budaya Indonesia. Menurut Trenholm dan Jensen: ”Kapanpun kita berinteraksi dengan orang lain yang telah dibekali seperangkat pemahaman yang berbeda mengenai dunia, kita terlibat dalam komunikasi lintas budaya."

Komunikasi lintas budaya terjadi bila produsen pesan adalah anggota suatu budaya dan penerimanya adalah anggota suatu budaya lainnya. Kita segera dihadapkan kepada masalahmasalah yang ada dalam suatu situasi dimana suatu pesan disandi dalam suatu budaya dan harus disandi balik dalam budaya lain, budaya mempengaruhi orang yang berkomunikasi. Budaya bertanggung jawab atas seluruh perbendaharaan perilaku komunikatif dan makna yang dimiliki setiap orang. Konsekuensinya, perbendaharaan yang dimiliki dua orang yang berbeda budaya akan berbeda pula, yang dapat menimbulkan segala macam kesulitan. Namun melalui studi dan pemahaman atas komunikasi lintas budaya, kita dapat mengurangi atau hampir menghilangkan kesulitan-kesulitan ini.

Kehidupan majemuk bangsa Indonesia yang kompleks ditandai dengan kenyataan latar belakang sosial budaya etnis yang berbeda-beda. Dengan kenyataan tersebut tidaklah mudah bagi bangsa Indonesia untuk mewujudkan suatu integrasi dan menghindari konflik atau bahkan perpecahan (DeVito, 1997). Komunikasi antar budaya menjadi semakin penting karena meningkatnya mobilitas orang di seluruh dunia, saling ketergantungan ekonomi diantara banyak 
negara, kemajuan teknologi komunikasi, perubahan pola imigrasi dan politik membutuhkan pemahaman atas kultur yang berbeda-beda (DeVito, 1997). Komunikasi antara budaya sendiri lebih menekankan aspek utama yakni komunikasi antar pribadi diantara Komunikator dan Komunikan yang kebudayaannya berbeda (Mulyana, 1996).

Potensi konflik yang besar pada masyarakat Indonesia disebabkan oleh terpecahpecahnya masyarakat kedalam kelompok-kelompok berdasarkan identitas cultural mereka. Identititas cultural berasal dari identitas sosial yang ada dalam diri masing-masing individu. Setiap orang memiliki tiga level identitas yang tergantung dari konteksnya, mungkin atau tidak mungkin menonjol dalam hubungan kita dengan yang lainnya. Tiga level tersebut adalah pribadi, hubungan dan komunal. Identitas pribadi merupakan hal-hal yang membuat anda unik dan berbda dari orang lain. Identitas hubungan merupakan hasil dari hubungan anda dengan orang lain seperti suami/istri, guru/murid atau eksekutif/manajer. Identitas komunal biasanya dihubungkan dengan komunitas berskala besar seperti kewarganegaraan, etnis, gender atau agama dan aliran politik (Samovar, Porter, McDaniel, 2010:186).

Identitas komunal menurut Hall sama dengan identitas sosial menurut Taylor dan Gudykunst yang dianggap pemnting dalam komunikasi antar budaya: Identitas sosial dapat berdasarkan keanggotaan kita dalam kategori demografis (misalnya: kewarganegaraan, etnis, gender, umur, kelas sosial), peranan kita (misalnya: pelajar, dosen, orang tua), keanggotaan kita dalam organisasi formal dan informal (misalnya partai politik, klub sosial), perkumpulan atau pekerjaan kita (misalnya ilmuwan, pekerja seni, tukang kebun) atau keanggotaan kita dalam kelompok cacat (misalnya gelandangan, pengidap AIDS) (Samovar, Porter, McDaniel, 2010).

Sementara menurut Ting-Toomey (1999:30) identitas cultural sebagai perasaan (emotional significance) dari individu-individu yang ikut memiliki (sense of belonging) atau bergabung dalam kelompok budaya tertentu. Pada masyarakat Indonesia banyak terdapat pemukiman-pemukiman warga berdasarkan kelompok budaya masing-masing. Misalnya: Kampung Jawa, Kampung Arab, Kampung Bali, Pecinan dan lain-lain. Hal ini ada sisi positif dan negatifnya. Di satu sisi, permukiman yang terpusat pada satu budaya ini akan menciptakan rasa aman sekaligus nyaman bagi para penghuninya. Namun di sisi lain akan menimbulkan konflik ketika dihadapkan dengan karakteristik masyarakat Indonesia yang pluralis. Pada masyarakat yang seperti ini akan terjadi adanya ketidaktulusan dari kedua belah pihak. Komunikasi yang terjadi dalam interaksi tersebut hanya sekedar untuk berbasa basi. Komunikasi tidak menyampaikan pesan yang sebenarnya. 
Sebagaimana budaya dan etnis mempengaruhi identitas diri, cara dimana individu memproyeksikan identitas dirinya juga bervariasi dalam budaya yang berbeda. Rasa akan diri seseorang merupakan hal yang sadar maupun tidak sadar. Maksudnya, dalam banyak budaya yang berbeda, orang-orang membawa citra yang mereka presentasikan kepada orang lain secara kebiasaan atau strategis. Ting Toomey percaya bahwa bagaimana kita mempersepsikan rasa akan diri kita dan bagaimana kita ingin orang lain untuk mempersepsikan kita merupakan hal yang sangat penting dalam pengalaman komunikasi kita (West and Turner, 2008).

Asumsi dari teori Face negotiation dari Ting Toomey ini salah satunya adalah mengenai konflik yang bekerja sama dengan budaya dan face. Konflik dapat merusak muka sosial seseorang dan dapat mengurangi kedekatan hubungan antara dua orang. Konflik adalah "forum" bagi kehilangan muka dan penghinaan terhadap muka. Konflik mengancam muka kedua pihak dan ketika terdapat negosiasi yang tidak bersesuaian dalam bagaimana menyelesaikan konflik tersebut (seperti menghina orang lain, memaksa kehendak dan seterusnya), konflik dapat memperparah situasi. Cara manusia disosialisasikan ke dalam budaya mereka mempengaruhi bagaimana mereka akan mengelola konflik. Maksudnya, dalam beberapa budaya, seperti Amerika Serikat menganggap bahwa menunjukan perbedaan diantara dua orang sebagai hal yang penting; sementara budaya lain yakin bahwa konflik harus ditangani secara diam-diam.

Pada konteks komunikasi antar budaya, ketidaktulusan dalam menjalin interaksi disebut dalam konsep mindlessness, yaitu orang yang sangat percaya pada kerangka referensi yang sudah dikenal, kategori-kategori yang bersifat rutin dan cara-cara melakukan sesuatu yang lazim (TingToomey, 1999:46). Ketika seseorang melakukan kontak budaya dengan orang asing, maka individu yang berada dalam keadaan mindlessness menjalankan komunikasinya seperti kegiatan rutinitas yang tidak dilandasi dengan kesadaran berfikir. Individu seperti ini lebih bersifat resktif daripada proaktif.

Perilaku komunikasi yang mindlessness disebabkan oleh ketidakpastian (uncertainty) dan kecemasan (anxiety) yang dialami seseorang. Menurut Griffin, (2000:396-397); Gudykunst \& Kim, (1997:14) ketidakpastian dipahami sebagai ketidakmampuan seseorang untuk memprediksikan atau menjelaskan perilaku, perasaan, sikap atau nilai-nilai yang diyakini orang lain. Sedangkan kecemasan merupakan perasaan gelisah, tegang, khawatir, atau cemas tentang seseuatu yang akan terjadi. Ketidakpastian merupakan pikiran (thought) dan kecemasan merupakan perasaan (feeling). Ketidakpastian dan kecemasan merupakan faktor-faktor penyebab dari kegagalan komunikasi dalam situasi antar kultural. Ketidakpastian dan kecemasan yang relatif tinggi dari masing-masing individu ketika berusaha melakukan komunikasi antar budaya 
pada saatnya akan menyebabkan munculnya tindakan atau perilaku yang tidak fungsional atau memicu terjadinya konflik.

Konflik pada dasarnya merupakan situasi yang melibatkan paling tidak dua pihak, karena itu konsep pertama yang harus dibahas adalah pihak-pihak yang terlibat dalam konflik. Setiap pihak (partai) pada dasarnya harus dilihat sebagai satuan perilaku (behavior unit), yaitu suatu jumlah atau organisasi yang walaupun di dalamnya ada kedudukan yang berbeda-beda, tetap bisa didentifikasi jati diri dan batas-batas umumnya. Satuan perilaku bisa berbentuk pribadi, keluarga, spesies binatang atau kelas ekonomi (Boulding dalam Habib, 2007).

Sedangkan pertikaian dapat diartikan sebagai suatu situasi persaingan dimana kelompok bertikai sadar ada ketidakcocokan kedudukan potensial di masa depan dimana masing-masing kelompok bertikai berharap memperoleh kedudukan yang tidak cocok dengan harapan kelompok lain. Jadi, pengertian konflik ini menyertakan dua kata pokok, yaitu kesadaran dan harapan.

Menurut Ting Tomey (2008) konflik antar budaya dapat diatasi dengan Face Negotiation. Asumsi dari teori ini: 10 identitas diri penting dalam interaksi interpersonal dan individu-individu menegosiasikan identitas mereka secara berbeda dalam budaya yang berbeda. 2) Manajemen konflik dimediasi oleh muka dan budaya. 3) Tindakan-tindakan tertentu mengancam citra diri seseorang yang ditampilkan.

Budaya menurut Ting Tomey (2008) dapat dibagi menjadi dua, yaitu individualistik dan kolektivitas. Budaya individualistik adalah budaya kemandirian dan budaya kolektivitas adalah budaya saling ketergantungan. Kedua budaya ini memainkan peranan penting dalam cara bagaimana facework dan konflik dikelola.

Seluruh proses komunikasi pada akhirnya menggantungkan keberhasilan pada tingkat ketercapaian tujuan komunikasi, yakni sejauh mana para partisipan memberikan makna yang sama atas pesan yang dipertukarkan. Itulah yang dikatakan sebagai komunikasi antar budaya yang efektif, sering disebut pula dengan efektivitas komunikasi antar budaya. Berikut ini ditunjukkan beberapa konsep yang berkaitan dengan efektivitas komunikasi (antar budaya). Charley H. Dodd (1991:272) menjelaskan beberapa aspek yang patut dikaitkan dengan efektivitas komunikasi antar budaya, yaitu: Variabel kognitif dan personal yang dipakai untuk menerangkan komunikasi antar budaya yang efektif terinci atas: (1) variabel yang berorientasi pada perilaku kerja antar budaya, (2) perilaku yang berorientasi pada diri sendiri,(3) etnosentrisme, (4) toleransi terhadap situasi yang ambigu, (5) empati, (6) keterbukaan, (7) kompleksitias kognitif, (8) menyenangkan hubungan antar pribadi, (9) control personal, (10) kemampuan inovatif, (11) harga diri, dan (12) daya serap informasi. 
Pengaruh budaya atas individu dan masalah-masalah penyandian dan penyandian balik pesan dapat digambarkan dalam model menurut Porter dan Samovar (2010) di bawah ini:

\section{Mode I of Interc ultura I Communlcation (Porter and Samovar, 1982:33)}

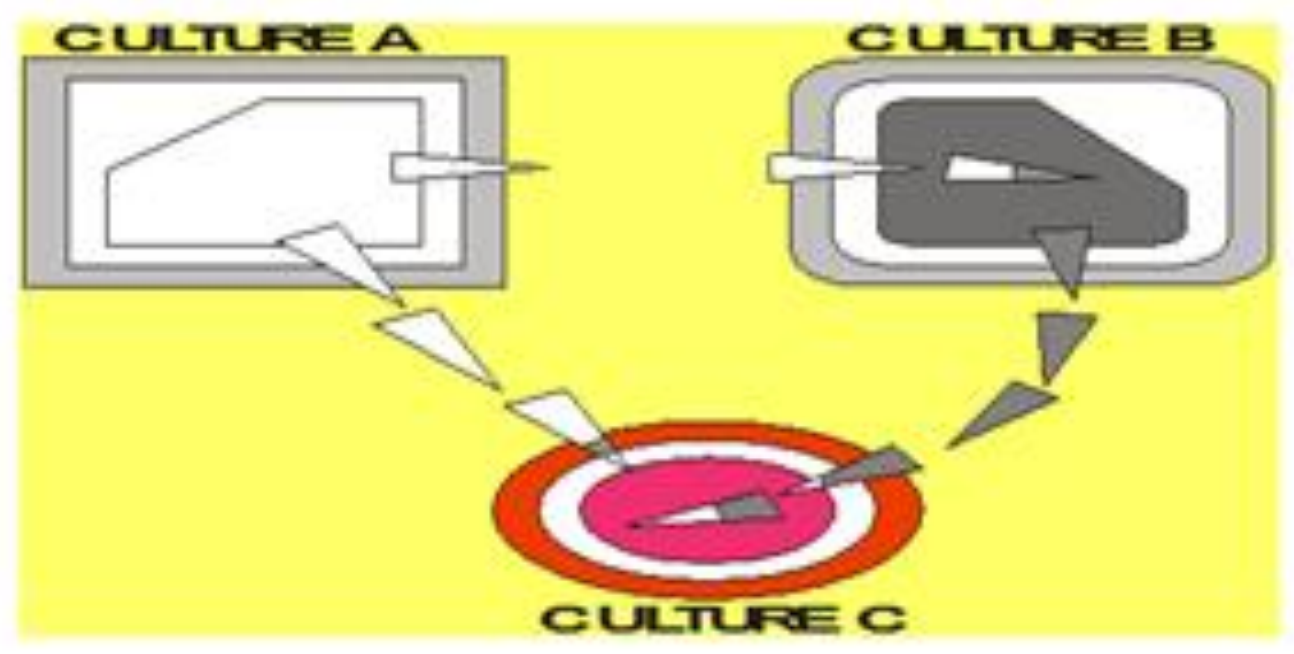

Tiga budaya diwakili dalam model ini oleh tiga bentuk geometrik yang berbeda. Budaya A dan budaya B relatif sama dan masing-masing diwakili oleh segi empat dan suatu segi delapan yang tidak beraturan yang hapir menyerupai segi empat. Budaya $\mathrm{C}$ sangat berbeda dari budaya $\mathrm{A}$ dan budaya B. Pada setiap budaya ada bentuk lain yang agak serupa dengan bentuk budaya. Ini menunjukan individu yang telah dibentuk oleh budaya yang mempengaruhinya. Hal ini menunjukan dua hal. Pertama, ada pengaruh-pengaruh lain disamping budaya yang membentuk individu. Kedua, meskipun budaya merupakan kekuatan dominan yang mempengaruhi individu, orang-orang dalam suatu budaya pun mempunyai sifat-sifat yang berbeda.

Penyandian dan penyandian balik pesan lintas budaya dilukiskan oleh panah-panah yang menghubungkan budaya-budaya itu. Panah-panah ini menunjukan pengiriman pesan dari budaya yang satu ke budaya yang lainnya. Ketika suatu pesan meninggalkan budaya dimana ia di sandi, pesan itu mengandung makna yang dikehendaki oleh penyandi (encoder). Hal Ini ditunjukan oleh panah yang meninggalkan suatu budaya yang mengandung pola yang sama seperti pola yang ada dalam individu penyandi. Ketika suatu pesan sampai pada budaya dimana pesan itu harus di sandi balik, pesan itu mengalami perubahan dalam arti pengaruh budaya penyandi balik (decoder) telah menjadi bagian dari makna pesan. Makna yang terkandung dalam pesan yang asli telah berubah selama fase penyandian balik dalam komunikasi antar budaya, oleh karena pembendaharaan perilaku komunikatif dan makna yang dimiliki decoder tidak mengandung makna-makna budaya yang sama seperti yang dimiliki encoder. 
Derajat pengaruh budaya dalam situasi-situasi komunikasi antar budaya merupakan fungsi perbedaan antara budaya-budaya yang bersangkutan. Ini ditunjukan pada model oleh derajat perubahan pola yang terlihat pada panah-panah pesan. Perubahan antara budaya A dan budaya B lebih kecil daripada perubahan antara budaya A dan budaya C. Ini disebabkan oleh kemiripan yang lebih besar antara budaya A dan budaya B. Pembendaharaan perilaku komunikatif dan makna keduanya mirip dan usaha penyandian balik yang terjadi, oleh karenanya, menghasilkan makna yang mendekati makna yang dimaksudkan dalam penyandian pesan asli. Tetapi oleh karena budaya $\mathrm{C}$ tampak sangat berbeda dengan budaya $\mathrm{A}$ dan budaya $\mathrm{B}$ penyandian baliknya juga sangat berbeda dan lebih menyerupai pola budaya $\mathrm{C}$.

Model tersebut menunjukkan bahwa bisa terdapat banyak ragam perbedaan budaya dalam komunikasi antar budaya. Komunikasi antar budaya terjadi dalam banyak ragam situasi yang berkisar dari interaksi-interaksi antara orang-orang yang berbeda budaya secara ekstrim hingga interaksi-interaksi antara orang-orang yang mempunyai budaya dominan yang sama tetapi mempunyai subkultur atau subkelompok yang berbeda. Bila kita melihat perbedaanperbedaan yang berkisar pada suatu skala minimum-maksimum, tampaklah bahwa besarnya perbedaan dua kelompok budaya tergantung pada keunikan sosial kelompok-kelompok budaya yang dibandingkan. Walaupun skala ini sederhana, skala tersebut memungkinkan kita memeriksa suatu aksi komunikasi antar budaya dan meneropong efek perbedaan-perbedaan budaya. Untuk memahami skala ini, kita akan melihat beberapa contoh perbedaan budaya yang berada pada skala tersebut.

Contoh pertama menunjukan suatu perbedaan yang maksimum antara budaya Asia dan budaya Barat. Ini dilambangkan dalam suatu percakapan antara dua orang petani, seorang dari suatu ladang dipinggiran kota Beijing dan seorang lainnya dari suatu ladang luas dan modern dekat kota Des Moines. Dalam contoh ini, jumlah faktor budaya berbeda yang dapat kita temukan adalah jumlah terbesar. Penampakan fisik, agama, filsafat, sikap-sikap sosial, bahasa, pusaka, konsep-konsep dasar tentang diri sendiri dan alam semesta, dan derajat perkembangan teknologi, adalah sebagian saja diantara faktor-faktor budaya yang berbeda tajam. Kita pun harus mengetahui bahwa kedua petani ini punya beberapa persamaan dalam bertani dan gaya hidup perdesaan. Dalam beberapa aspek pola budaya, mereka mungkin lebih mirip daripada bila dibandingkan dengan orang-orang dari budaya mereka sendiri yang tinggal di suatu kota metropolitan. Dengan kata lain, petani asal Iowa tersebut mungkin punya lebih banyak persamaan dengan petani Cina daripada dengan seorang pedagang saham di New York. 
Perbandingan antara budaya yang terpisah tapi serupa atau antara subbudaya atau subkelompok - anggota-anggota setiap kelompok budaya mempunyai lebih banyak persamaan daripada kelompok-kelompok yang dibandingkan dalam contoh-contoh pada ujung skala maksimum. Mereka mungkin berbicara bahasa yang sama, menganut agama yang sama, pergi ke sekolah-sekolah yang sama dan tinggal di daerah geografis yang sama. Namun kelompokkelompok masih memiliki budaya yang agak berbeda; mereka tidak memiliki pengalamanpengalaman yang sama dan tidak pula memiliki persepsi-persepsi yang sama. Mereka memandang dunia dengan cara yang berbeda. Gaya hidup mereka mungkin berbeda, dan kepercayaan-kepercayaan, nilai-nilai, dan sikap-sikap mereka tak semuanya sama. Oleh karena mereka mempunyai budaya yang serupa, perbedaan mereka terutama terletak pada aspek-aspek persepsi sosial mereka yang terbatas. Apabila hal ini tidak dapat dipahami bersama atau mendapatkan pemahanan bersama maka akan menimbulkan konflik diatara dua budaya yang berbeda tersebut.

Persepsi sosial adalah proses pemberian makna kepada objek-objek sosial dan peristiwa yang kita temukan di lingkungan kita dan merupakan suatu aspek komunikasi yang sangat penting. Budaya mempengaruhi proses persepsi sedemikian rupa sehingga kita memiliki tatanantatanan perseptual yang bergantung pada budaya. Tatanan-tatanan perseptual ini tidak saja mempengaruhi stimuli mana yang mencapai kesadaran kita, tetapi lebih penting lagi, mempengaruhi penilaian kita terhadap stimuli - pemberian makna terhadap stimuli. Komunikasi antarbudaya akan lebih dapat dipahami sebagai perbedaan budaya dalam mempersepsi objekobjek sosial dan kejadian-kejadian. Hambatan komunikasi yang disebabkan perbedaan persepsi ini dapat dikurangi dengan pengetahuan dan pemahaman atas faktor-faktor budaya yang dapat berbeda yang harus disertai dengan keinginan yang tulus untuk berkomunikasi antar budaya yang berhasil. Apabila hal ini tidak dapat diatasi maka akan menimbulkan konflik atau perpecahan.

Suatu keinginan yang tulus untuk melakukan komunikasi yang efektif adalah penting, sebab komunikasi yang berhasil mungkin tidak hanya terhambat oleh perbedaan-perbedaan budaya, tetapi juga oleh sikap-sikap yang tidak bersahabat atau bermusuhan. Prasangkaprasangka rasial dan kesukuan dapat menghambat komunikasi antar budaya. Bila terdapat maslah-masalah ini, pengetahuan budaya dan keterampilan berkomunikasi tidak akan menolong. Perhatian kita terutama tertuju pada situasi-situasi dimana terdapat perbedaan-perbedaan budaya dalam penyandian dan penyandian balik atas pesan-pesan verbal dan non-verbal selama interaksi antarbdaya serta masalah-masalah yang melekat pada situasi-situasi tersebut. Hal ini akan terasa sekali apabila komunikasi ini terjadi dalam level interaksi hubungan antar pribadi. 
Menurut Billie J. Watstroom (1992:133), efektivitas komunikasi antar personal ditentukan oleh beberapa faktor, yaitu (1) menghormati pribadi orang lain, (2) mendengarkan dengan senang hati, (3) mendengarkan tanpa menilai, (4) keterbukaan terhadap perubahan dan keragaman, (5) empati, (6) bersikap tegas dan (7) kompetensi komunikasi.

Sementara menurut Mulyana (1996) ada karakteristik interaksi antar pribadi yang efektif yang diturunkan dari model humanistik dan yang diturunkan dari model pragmatik. Kesepuluh karakteristik ini khususnya penting dalam komunikasi antar budaya dan dapat bermanfaat dalam konteks kultural. Dalam menelaah karakteristik-karakteristik ini sadarilah bahwa mereka belum tentu efektif untuk semua kultur. Begitu juga, tidak semua perilaku verbal dan non-verbal mempunyai makna yang sama dalam semua kultur. Sebagai contoh, Maria Rodriguez (1988) membutikan bahwa kaum kulit hitam dan kaum Hispannik menilai sikap tegas (assertiveness) secara berbeda. Begitu pula, Hecht dan Ribeau (1984) membuktikan bahwa kaum kulit putih, kulit hitam dan Hispanik mendefinisikan apa yang dinamakan komunikasi yang memuaskan secara berbeda. Kesepuluh karakteristik komunikasi yang efektif tersebut, yaitu: (1) Keterbukaan. Bersikaplah terbuka terhadap perbedaan yang ada di antara orang-orang. Terutama bersikaplah terbuka terhadap perbedaan nilai, kepercayaan, dan sikap, selain juga terhadap perilaku. Tidaklah berarti anda harus mengikutinya, cukup asal anda menyadari bahwa orang itu berbeda. (2) Empati. Tempatkanlah diri anda pada posisi lawan bicara yang berasal dari kultur yang berbeda. Cobalah melihat dunia dari sudut pandang yang berbeda ini. Cara ini akan memungkinkan anda berkomunikasi secara lebih efektif dan memberikan perspektif baru bagi anda dalam melihat kultur sendiri dan biarkanlah lawan bicara anda tahu bahwa anda merasa seperti yang mereka rasakan. Isyaratkanlah empati ini dengan ekspresi wajah, gerak-gerik yang penuh minat dan perhatian, serta tanggapan yang mencerminkan pengertian dan kesependapatan. (3) Sikap mendukung. Deskriptif, jangan evaluatif; spontan, jangan strategik; provisional, jangan memastikan. (4) Sikap positif. Komunikasikan sikap positif. Ini khususnya penting dalam situasi antar budaya karena begitu banyak hal yang tidak dikenal atau diketahui. Sebagai akibatnya, anda tidak mampu memperkirakan apa yang dipikirkan dan dirasakan orang lain. Karenanya, buatlah lawan bicara merasa nyaman dengan mengkomunikasikan sikap yang positif. (5) Kesetaraan. Warganegara dari negara-negara industri maju (khususnya Amerika) mempunyai reputasi sebagai orang yang merasa dirinya lebih unggul. Hilangkanlah reputasi ini dengan selalu bersikap bahwa kita berkomunikasi dengan pihak yang setara. (6) Percaya diri. Satu keterampilan penting dalam komunikasi antar budaya adalah mentoleransi ambiguitas - tetap percaya diri dan tenang dalam setiap situasi yang belum pernah anda alami. Tentu saja, hindari sikap sombong. (7) Kedekatan (immediacy). Kedekatan menyatukan orang. Kedekatan 
membantu mengatasi perbedaan. Dalam komunikasi antar budaya kualitas ini menjadi sangat penting karena besarnya perbedaan antara anda dan lawan bicara. Komunikasikanlah rasa kebersamaan untuk mengatasi adanya perbedaan antar budaya. (8) Manajemen interaksi. Khususnya bersikaplah sensitif terhadap perbedaan dalam cara mengambil alih pembicaraan. Banyak orang Amerika, terutama mereka yang berasal dari kota-kota besar, mempunyai kebiasaan memotong pembicaraan orang lain. Beberapa kultur menganggap ini tidak sopan. Kultur lain memandang ini sebagai pertanda interaksi yang menyenangkan. (9) Daya ekspresi. Bila perbedaan cukup besar, beberapa orang merasa tidak nyaman dan tidak yakin akan diri mereka sendiri. Tanggulangilah keadaan ini dengan mengkomunikasikan keterlibatan tulus dalam interaksi. Biarkanlah lawan bicara bahwa anda menikmati interaksi ini: Tersenyumlah! (10) Berorientasi kepada Pihak lain. Sadarilah bahwa setiap orang mempunyai andil dalam interaksi. Jangan memonopoli percakapan dengan hanya membicarakan diri sendiri, memilihkan topik pembicaraan dan hanya membicarakan pengalaman anda sendiri. Sebaliknya, arahkan percakapan kepada lawan bicara. Ajukan pertanyaan, gunakan keterampilan mendengarkan yang efektif dan aktif, dan perlihatkan minat terhadap hal-hal yang menarik lawan bicara.

Konflik komunikasi antar budaya dapat diselesaikan melalui dialog yang baik. William Powers dan David Lowrey menyatakan bahwa komunikasi yang efektif adalah dasar dari komunikasi yang jitu, yaitu komunikasi yang sejalan dengan kognisi (apa yang dipikirkan) dari dua atau tiga individu yang berkomunikasi. Harry Triandis (1997) menegaskan bahwa efektivitas komunikasi itu meliputi isomorphic attributions, yaitu bagaimana 'menggambarkan' (description) sesuatu menjadi sama (Powers dan Lowrey, 1984:84).

Everet Rogers dan Lawrence Kincaid (dalam Figueroa, Kincaid, et all, 2002:5) mengatakan bahwa komunikasi antar budaya yang efektif terjadi jika muncul mutual understanding atau komunikasi yang saling memahami. Yang dimaksudkan dengan saling memahami adalah keadaan dimana seseorang dapat memperkirakan bagaimana orang lain memberi makna atas pesan yang dikirim dan menyandi baik pesan yang diterima. Mutual understanding akan terjadi dalam komunikasi dialog. Satu hal yang patut diingat bahwa pemahaman timbal balik itu tidak sama dengan pernyataan setuju, tapi hanya menyatakan dua pihak sama-sama mengerti makna dari pesan yang dipertukarkan itu

Mengenai pengelolaan konflik, Ting Tomey (2008) menawarkan beberapa gaya, yaitu menghindar, menurut, kompromi, mendominasi dan mengintegrasikan. Gaya menghindar, orang tersebut akan berusaha menjauhi dan menghindari pertukaran yang tidak menyenangkan dengan orang lain (Saya sibuk atau saya tidak ingin membicarakannya). Gaya menurut mencakup 
akomodasi pasif yang berusaha memuaskan kebutuhan orang lain atau sepakat dengan saransaran dari orang lain (Apapun yang ingin anda lakukan saya tidak keberatan). Gaya kompromi, individu berusaha untuk menemukan jalan tengah untuk mengatasi jalan buntu dan menggnakan pendekatan memberi-menerima sehingga kompromi dapat dicapai (Saya akan mengorbankan minggu pertama liburan saya; Anda juga melakukan yang sama). Gaya mendominasi mencakup perilaku-perilaku yang menggunakan pengaruh, wewenang atau keahlian untuk menyampaikan ide atau untuk mengambil keputusan (Saya sedang dalam posisi yang terbaik untuk membicarakan masalah ini). Terakhir, Gaya mengintegrasikan digunakan untuk menemukan solusi masalah (Saya rasa kita harus menyelesaikan masalah ini bersama-sama). Dalam masalah integrasi, setiap individu membutuhkan perhatian yang tinggi untuk diri sendiri dan orang lain.

Ting Toomey menyatakan bahwa terdapat beberapa hubungan antara gaya konflik dan facework (West and Turner, 2008). Pertama, baik gaya manajemen menghindar dan menurut mencerminkan pendekatan pasif dalam menghadapi konflik. Gaya manajemen berkompromi menunjukan kebutuhan muka bersama dengan menemukan jalan tengah dari sebuah konflik. Terakhir gaya mendominasi menunjukan kebutuhan muka diri yang tinggi serta kebutuhan akan kontrol terhadap konflik, sementara gaya manajemen mengintegrasikan mengindikasikan tingkat kebutuhan muka diri atau muka lain dalam resolusi konflik. Hasil penelitian Ting Toomey pada lima budaya yang berbeda (Jepang, Cina, Korea Selatan, Taiwan dan Amerika Serikat) menujukkan bahwa (1) anggota-anggota dari budaya Amerika Serikat menggunakan lebih banyak gaya mendominasi dalam manajemen konflik. (2) Orang Taiwan menyatakan bahwa mereka lebih banyak menggunakan gaya mengintegrasikan dalam manajemen konflik. (3) Orang Cina dan Taiwan menggunakan lebih banyak gaya manajemen menurut. (4) Orang Cina lebih banyak menggunakan tingkat manajemen menghindar yang tinggi sebagai gaya manajemen konflik dibandingkan kelompok budaya lainnya. (5) Orang Cina menggunakan tingkat berkompromi yang lebih tinggi dari budaya-budaya yang lain. (6) Budaya kolektivistik (Cina, Korea dan Taiwan) memiliki tingkat perhatian terhadap muka lain yang lebih tinggi.

Berdasarkan penelitian Ting Toomey ini membuktikan bahwa dengan adanya keanekaragaman budaya mempengaruhi bagaimana konflik dikelola. Hal ini juga akan terjadi di negara kita Indonesia. Indonesia yang memiliki keragaman budaya akan mempengaruhi bagaimana konflik dikelola. Masing-masing budaya akan membedakan bagaimana mereka mengelola konfliknya. Hal ini harus dipahami oleh masyarakat Indonesia secara keseluruhan, karena akan dapat mempertahankan integrasi bangsa Indonesia. 
Mulyana (1996) menyarankan langkah pertama dalam mengidentifikasi pintu masuk atau pedoman komunikasi antar budaya adalah menyadari bahwa hambatan-hambatan yang ada perlu dihindari. Sebagai pedoman, dapat dibaca beberapa saran berikut:

1. Sadarilah perbedaan antara anda dan orang yang kulturnya berbeda. Bila ragu, bertanyalah; jangan mengasumsikan kesamaan. Tetapi, pada waktu yang sama, sadarilah pula manfaat mencari kesamaan dan menekankannya pada saat berkomunikasi.

2. Sadarilah bahwa perbedaan selalu ada dalam kelompok apa pun. Jangan bersikap stereotipe, terlalu menggeneralisasi atau mengasumsikan bahwa perbedaan dalam satu kelompok tidak penting.

3. Ingatlah bahwa makna ada pada orang dan bukan pada kata-kata atau gerak-gerik. Ceklah makna yang anda berikan dengan maksud lawan bicara. Pastikanlah bahwa setiap kesamaan atau perbedaan dalam makna yang anda asumsikan memang benar-benar ada.

4. Ingatlah akan adat kebiasaan budaya yang berlaku dalam sebarang konteks komunikasi antarbudaya. Ingatlah contoh mengenai orang Amerika dan orang Arab yang masing-masing mengikuti adat kebiasaan yang berbeda dalam hal jarak antar pribadi dalam komunikasi. Pekalah terhadap adat kebiasaan yang diikuti lawan bicara. Hati-hatilah jangan sampai anda menganggap bahwa adat andalah yang benar.

5. Hindari evaluasi negatif terhadap perbedaan kultur, baik secara verbal maupun nonverbal. Pandanglah adat kebiasaan budaya (kultur anda maupun kultur yang lain) sebagai bersifat arbitrer dan menyenangkan bukan sebagai sesuatu yang natural dan logis.

6. Hindari kejutan budaya dengan mempelajari sebanyak mungkin kultur yang akan anda masuki. Bacalah, berbicaralah dengan penduduk asli dan mereka yang mempunyai pengalaman, dan saksikanlah film, misalnya.

Dibalik semua kendala yang ada, maka upaya penyelesaian permasalahan pluralitas budaya sekaligus menunjukkan peran komunikasi antar budaya dalam terwujudnya integrasi nasional, yakni dapat dilakukan dengan cara: (1) menjadi manusia antar budaya atau manusia multicultural yang dapat memahami dan toleran dengan keberagaman budaya yang dimiliki Negara Indonesia. (2) Menciptakan kehidupan masyarakat multi kultural; dilakukan dengan meningkatkan toleransi dan apresiasi antar budaya. Proses ini dapat diawali dengan peningkatan pengetahuan masyarakat tentang kebhinekaan budaya. (3) Peningkatan peran media komunikasi, terutama untuk melakukan sensor secara substantif yang berperan sebagai korektor terhadap penyimpangan norma sosial yang dominan. Salah satu caranya dengan melancarkan tekanan 
korektif terhadap subsistem yang mungkin keluar dari keseimbangan fungsional. Eksposure perbuatan yang merugikan kepentingan umum dan melecehkan nilai-nilai yang dijunjung tinggi oleh masyarakat, harus disiarkan dengan fungsi sebagai pemeliharaan kestabilan. Sedang kontrol secara distributif, berfungsi memelihara keseimbangan sistem melalui diseminasi selektif dan berbagai ragam teknik-teknik penyebaran maupun penyaringan informasi, yang mungkin dapat mengundang kemelut dalam masyarakat atau menimbulkan perpecahan, justru media komunikasi dituntut untuk dapat menampilkan berbagai informasi yang bersifat apresiatif terhadap budaya masyarakat lain. (4) Pelaksanaan pendidikan yang berbasis budaya dapat menjadi pilihan karena pendidikan berbasis adat tidak akan melepaskan diri dari prinsip bahwa manusia adalah faktor utama, sehingga manusia harus selalu merupakan subyek sekaligus tujuan dalam setiap langkah dan upaya perubahan. Nilai-nilai budaya tradisional dapat terinternalisasi dalam proses pendidikan baik di lingkungan keluarga, pendidikan formal maupun non formal. Khususnya pendidikan di sekolah diperlukan adanya paradigma baru yang dapat menyajikan model dan strategi pembelajaran yang dapat menseimbangkan proses homonisasi. Tujuannya agar dapat terbentuk manusia yang bisa mengelola konflik, menghargai kemajemukan, serta dapat tegar menghadapi arus perubahan. Caranya dengan mempertajam sense of belonging, self of integrity, sence of participation dan sence of responsibility sebagai benteng terhadap pengaruh faktor eksternal tersebut. Transformasi budaya harus dipandu secara pelan-pelan, jadi hal ini bukanlah merupakan revolusi yang dipaksakan.

\section{Kesimpulan dan Saran}

Pendekatan komunikasi antar budaya dapat menyelesaikan konflik yang terjadi dalam masyarakat Indonesia yang beragam budaya atau etnis. Komunikasi antar budaya dapat meningkatkan integrasi nasional melalui pemahaman, saling pengertian dan toleransi pada masing-masing budaya dan kebhinekaan budaya dalam masyarakat Indonesia. Masyarakat Indonesia dengan keberagaman etnis yang disatukan dalam identitas nasional sebagai bangsa Indonesia menurut pendekatan komunikasi antar budaya bersama-sama menciptakan jalinan persaudaraan guna mewujudkan keberagaman dalam satu kesatuan Integrasi Nasional Indonesia. 


\section{Daftar Pustaka}

Devito, Joseph., 1997, Komunikasi Antar Manusia, Profesional Books, Jakarta

Figueroa, Maria Elena, D. Lawrence Kincaid, Manju Rani, Gari Lewis, 2002, Communication for Social Change: An Integrated Model for Measuring the Process and Its Outcomes, The Rockefeller Foundation, New York

Fisher, Simon, (2001) Mengelola Konflik, Ketrampilan dan Strategi untuk Bertindak, Jakarta:The British Council

Griffin, Em, 2000, A First Look At Communication Theory (Fourth Edition), McGraw Hill, New York

Gudykunst, William B., 2002, Handbook of International and Intercultural Communication, (Second Edition), Thousan Oaks, California, SAGE Publications

Gudykunst, William B. \& Young Yun Kim, 1997, Communication With Strangers, An Approach to Intercultural Communication, (Third Edition), McGraw-Hill, New York

Mulyana, Deddy, 1996, Komunikasi Antar Budaya, RosdaKarya, Bandung

Samovar, Larry A., Richard E Porter, Edwin R. McDaniel, 2010, Komunikasi Lintas Budaya (Communication Between Cultures), Edisi 7, Penerbit Salemba Humanika, Jakarta

Ting-Toomey, Stella, 1999, Communicating Across Cultures, The Guilford Publications, New York

West, Richard, Lynn H. Turner, 2008, Pengantar Teori Komunikasi, Analisis dan Aplikasi, Terjemahan, Buku 2, Salemba Humanika, Jakarta 
Intentionally Blank 